\title{
New simple method for detection IgM antibodies against Salmonella typhi infection on human
}

\author{
M. Hatta ${ }^{1}$, L. Chairudin L ${ }^{1}$, Henk L. Smits ${ }^{2}$
}

\begin{abstract}
Abstrak
Prinsip metoda yang digunakan adalah penggunaan dipstick. Dipstick mengandung 2 pita horizontal; pita antigen mengandung antigen S. typhi (pita yang di bawah) dan pita kontrol (di atas). Dasar dari tes ini ialah pengikatan antibodi IgM manusia spesifik Salmonella dengan antigen spesifik Salmonella. IgM yang terikat dideteksi dengan konjugat anti human IgM. Tes ini dilakukan dengan pengenceran serum 1:50 dalam reagen deteksi, dipstick yang sudah dibasahi diinkubasi pada larutan tersebut. Timbulnya warna pada pita antigen memperlihatkan adanya antibodi IgM spesifik Salmonella pada sampel serum. Peran pewarnaan ini penting pada interpretasi hasil tes. Tersedia strip referensi warna untuk digunakan sebagai pembanding intensitas warna. Sebagai kesimpulan, metoda baru dan sederhana ini (dipstick) mungkin bermanfaat untuk mendeteksi IgM terhadap infeksi S. typhi pada manusia tanpa membutuhkan alat khusus dan ketrampilan dan dapat diterapkan pada perawatan kesehatan masyarakat di tingkat pedesaan.
\end{abstract}

\begin{abstract}
The principle of this method was using the dipstick. The dipstick contains two horizontal bands; an antigen band consisting of antigen prepared from S. typhi (lower band) and an internal control (upper band). The assay is based on the binding of human Salmonella specific IgM antibodies to the Salmonella specific antigen. Bound IgM antibodies are specifically detected with an anti-human IgM dye conjugate. The assay is performed by making a 1:50 dilution of sera in the detection reagent and incubating a wetted disptick in this solution. Staining of the antigen band reveals the presence of Salmonella-specific IgM antibodies in the serum sample. The strenght of the staining is important in the interpretation of the test result. The provided, coloured reference strip is used to compare the staining intensity. In conclusion, this new simple method (dipstick) may benefit for detect the IgM antibodies against $\mathrm{S}$. typhi infection on human without needed special equipment and skill and can be applied in public health care in village level.
\end{abstract}

\footnotetext{
${ }^{1}$ Microbiology Dept, UNHAS, Ujung Pandang, Indonesia

${ }^{2}$ Royal Tropical Institute, The Netherlands
} 